\title{
Effects of Cadmium and Ionizing Radiation on Histones in Rat Testes
}

\author{
Š. KLIMOVÁ, E. MIŠÚROVÁ \\ Institute of Biological and Ecological Sciences, Šafárik University, 04154 Košice, Slovak Republic \\ Received April 10, 2003 \\ Accepted October 26, 2004
}

\section{Abstract}

Klimová S̆., Mišúrová E: Effects of Cadmium and Ionizing Radiation on Histones in Rat Testes. Acta Vet Brno 2004, 73: 483-489.

Changes in constituent part of the chromatin, histones, were studied in testes of rats 1-21 days after administration of cadmium ( $3 \mathrm{mg} \mathrm{CdCl} 2 / \mathrm{kg}$ body mass i.p.) and/or whole body irradiation ( 3 Gy of gamma rays). It was found that administration of cadmium alone did not result in changes of histones; the ratio of H/DNA, however, decreased due to temporary increase in DNA concentration. Irradiation alone caused an initial increase in concentration and total content of histones, which was followed by gradual decrease in histone content and changes in relative proportion of individual histone fractions until the end of experiment. On day 21 after irradiation alone, also abrupt increase in H1t subfraction in $\mathrm{H} 1$ histone fraction was found. After combined treatment (cadmium administration $30 \mathrm{~min}$ before irradiation), the alterations of histones were similar as after irradiation alone but they were more expressed. This finding suggested that partial summation of the two factor effects on the testicular histones occurred after the combined treatment of rats.

Cadmium, gamma irradiation, rat, testes, histones

Cadmium is a highly toxic and carcinogenic environmental contaminant, which has no special biological role in animal organism (S mith et al. 1994; Koréneková et al. 2002). It is accumulated in the human body with a half-life exceeding 10 years and has been linked with a number of health problems including marked damage to testes and fertility reduction (Kelley 1999; Bench et all. 1999). Acute cadmium-induced damage to testes manifests itself by haemorrhagic inflammation, degeneration and dysfunction of the organ, morphological changes or apoptotic death of germinal cells, etc. (Xu et al. 1996; Y an et al. 1997; Zhou et al. 1999; W aalkes 2000). On the cellular level, the toxic effects of cadmium in some organs, e.g. testis, liver and brain, include alterations in permeability of plasma membranes, damage to nuclear and mitochondrial membranes, increase in chromatin condensation, ladder-like splitting of DNA and decrease in the total DNA content, respectively (Koizumi et al. 1996; Fasanyaodewumi et al. 1998; Klimová and Mišúrová 2001). Irreversible changes of genome may be caused by an oxidative DNA damage leading to DNA strand-breaks, DNA-protein cross-linking and inhibition of DNA repair (Oteiza et al. 1999).

Many cadmium-induced changes (e.g. oxidative damage to DNA, chromatin condensation, decrease in DNA content, apoptosis) are similar to those caused by other harmful factors, especially by ionizing radiation. The most striking effects of ionizing radiation include, however, inhibition of DNA synthesis and mitosis and especially increase in the number of chromosome abnormalities (Van Buul and Goudzwaard 1990; De Rooij and Grootegoed 1998; Gobé et al. 1999).

DNA is arranged in a complex with histones into a highly ordered compact and dynamic chromatin structure (Beato and Eisfeld 1997; Ren and Tong 1997; Smerdon and Concoli 1999). Histones are subjected to post-translational modifications that might

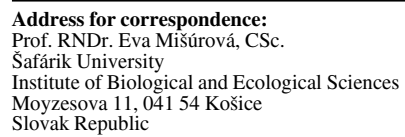


influence the packaging of DNA in nucleosomes and higher-order structure of chromatin fibres. By this way, the histones can regulate transcriptional activity in non-specific or genespecific manner and are involved in the processes of cell proliferation, differentiation and senescence (Berger 2002; Kouzarides 2002; Oki and Kamakaka 2002). Therefore, structural alterations and chemical modulations of DNA and histones induced by genotoxic agents and mainly the degree of DNA damage repair in the nuclear chromatin are the crucial events leading to cell death or cancerogenesis.

Until present, attention was paid particularly to the study of effects of ionizing radiation or other genotoxic factors on DNA structure, replication and repair of DNA damage in various tissues. Due to increasing level of some types of heavy metals and ionizing radiation in the environment, the biological effects of these agents should be considered in the context of combined exposure of an organism to multiply agents. In the present study, therefore, the alterations of histones were investigated in rat testes after administration of cadmium $(3 \mathrm{mg}$ $\mathrm{CdCl}_{2} / \mathrm{kg}$ body mass i.p.) and gamma irradiation ( $3 \mathrm{~Gy}$ ) alone or after combined treatment.

\section{Materials and Methods}

The experiment was performed with 80 male rats of the SD strain (Anlab Praha, Czech Republic), 6-week-old at the beginning of experiment. They were kept under standard vivarium conditions (temperature $22-24{ }^{\circ} \mathrm{C}$, natural light rhythm). Food and water were provided ad libitum. The animals were divided into four groups:

Non-treated control rats $(\mathrm{C})$

Rats treated with cadmium $(\mathrm{Cd})$

Rats irradiated with gamma rays (Ir)

Rats treated with cadmium before irradiation $(\mathrm{Cd}+\mathrm{Ir})$.

Cadmium administration

Cadmium $\left(\mathrm{CdCl}_{2}\right.$, Lachema Brno, Czech Republic) was administered i.p. at the dose of $3 \mathrm{mg} \cdot \mathrm{kg}^{-1}$ body weight alone or $30 \mathrm{~min}$ before irradiation (groups $\mathrm{Cd}$ and $\mathrm{Cd}+\mathrm{Ir}$, respectively).

Irradiation

Animals were total-body irradiated with the dose of $3 \mathrm{~Gy}$ by gamma rays from a ${ }^{60} \mathrm{Co}$ source (Chisostat Chirana, Czech Republic) at a dose rate of $0.150 \mathrm{~Gy} \cdot \mathrm{min}^{-1}$ (groups Ir and Cd + Ir).

The experimental conditions complied with the requirements for ethical standards of welfare and treatment of animals. The treatments were arranged in such a way that the rats achieved 9 weeks of their age at the time of sacrifice. At this age, the male rats are sexually mature; in the testes, spermatogonia A, spermatogonia B, spermatocytes I and spermatocytes II divide by mitotic, resp. meiotic divisions. However, due to the long duration of the first meiotic prophase, the spermatocytes I are the most numerous cells in the organ (Keeton and Gould 1986).

Isolation of cell nuclei

Cell nuclei were isolated according to the method of Grünicke et al. (1989).

Extraction of histones

Histones were extracted from the nuclei with $0.2 \mathrm{M} \mathrm{H}_{2} \mathrm{SO}_{4}$ for 1 hour. After precipitation and repeated washing of samples with acetone, concentration of histones was determined by the method of Lowry et al. (1951). Gel electrophoresis of histones

Separation and detection of individual histone fractions was carried out on polyacrylamide gels according to the method of Panyim and Chalkley (1969). After staining with amido black B, the relative proportion of the individual histone fractions was determined spectrophotometrically using a densitometer (Shimadzu CS-930, Japan). Detection of the individual fractions H2A, H2B and $\mathrm{H} 3$ was not always unambiguous and common values for these histone fractions $(\mathrm{H} 2+\mathrm{H} 3)$ are therefore given in Fig. 2.

Statistical analysis

The experimental data were statistically evaluated by Peritz' F-test (Harper 1984) and they are given as mean \pm SEM in the Figures and Table 1 .

\section{Results}

Quantitative changes

No quantitative changes of histones were found in the testes of rats treated with cadmium alone (Fig. 1). In rats exposed to gamma irradiation alone, a transient increase in histone concentration and total content occurred on day 1; at the following intervals, there was a gradual decrease especially in histone content. After the combined treatment a transient increase in histone concentration occurred on the 14th day; due to high 

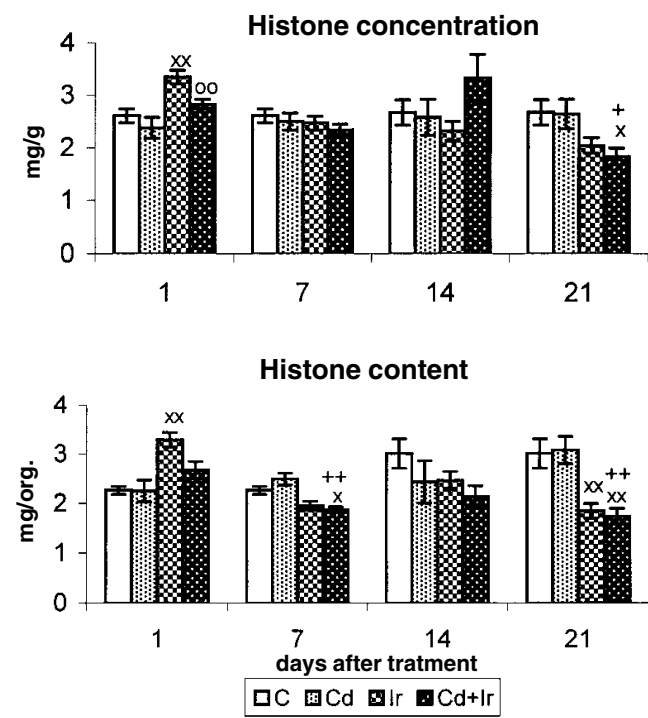

Fig. 1. Concentration and total content of histones ( $\mathrm{mg} / \mathrm{g}$ and $\mathrm{mg} /$ organ, respectively) in the testes of rats 1-21 days after administration of cadmium $(3 \mathrm{mg}$ $\mathrm{CdCl}_{2} / \mathrm{kg}$ i.p.) and/or whole-body irradiation ( $3 \mathrm{~Gy}$ of gamma rays) $( \pm$ SEM)

Statistical significance between experimental groups $(\mathrm{Cd}, \mathrm{Ir}, \mathrm{Cd}+\mathrm{Ir})$ and control group (C) x $P \leq 0.05 \times x P \leq 0.01$

Statistical significance between experimental groups $(\mathrm{Cd})$ and $(\mathrm{Cd}+\mathrm{Ir})+P \leq 0.05++P \leq 0.01$

Statistical significance between experimental groups (Ir) and (Cd+Ir) o $P \leq 0.05$ o $P \leq 0.01$

variation of values, however, the increase was statistically insignificant and it was not accompanied by adequate increase in the total histone content in the organ. The changes in total histone contents were more unequivocal than changes in histone concentrations and after combined treatment they manifested themselves by decrease, which was slightly deeper than after irradiation alone and on day 21 it was accompanied also by significant decrease in histone concentration.
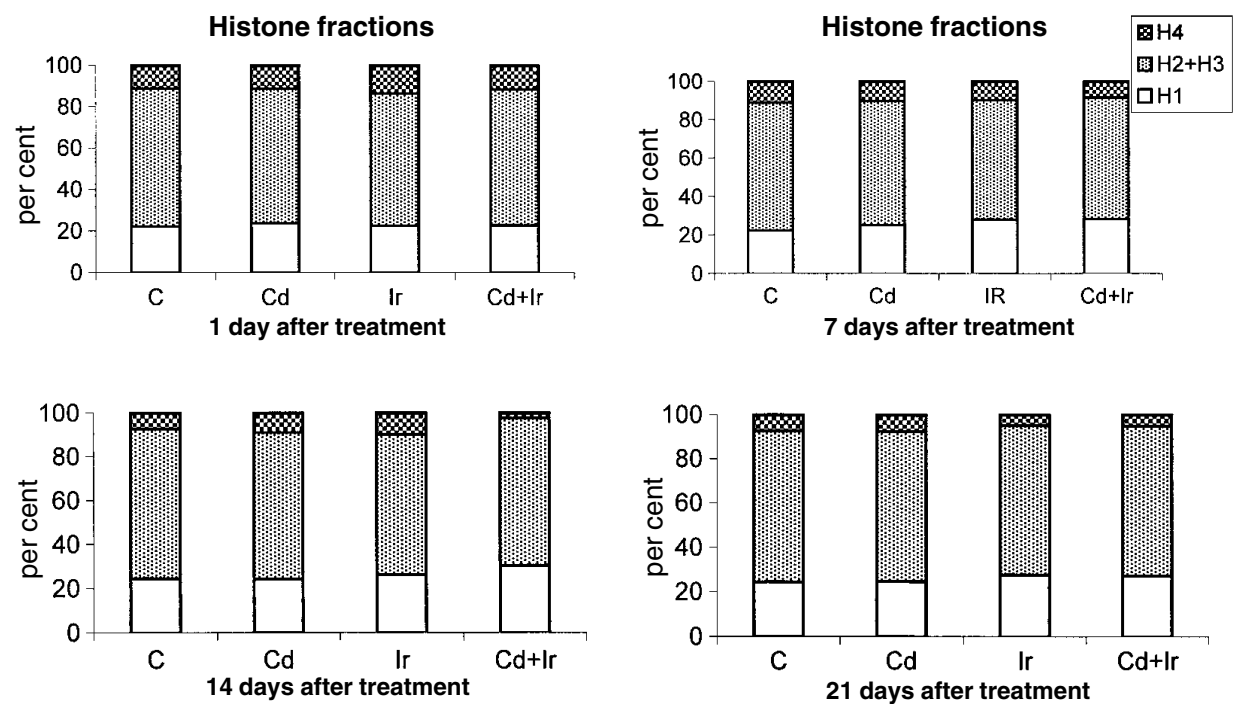

Fig. 2. Relative proportion (\%) of $\mathrm{H} 1, \mathrm{H} 2+\mathrm{H} 3$ and $\mathrm{H} 4$ fractions in histones extracted from the testes of rats at different periods after cadmium administration $(3 \mathrm{mg} \mathrm{CdCl} / \mathrm{kg}$ i.p.) and/or whole-body irradiation (3 Gy of gamma rays). 


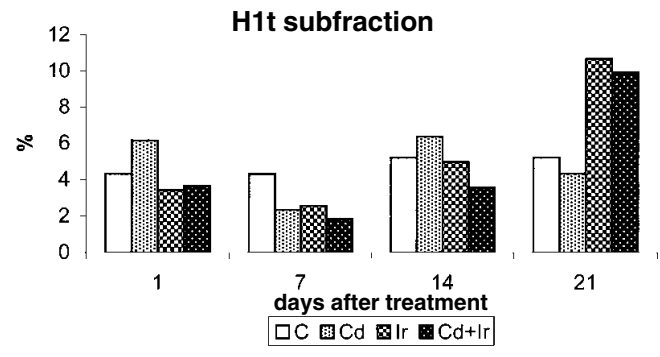

Fig. 3. Relative proportion (\%) of $\mathrm{H} 1 \mathrm{t}$ subfraction in $\mathrm{H} 1$ histone fraction in the testes of rats at different periods after cadmium administration ( $3 \mathrm{mg} \mathrm{CdCl}_{2} / \mathrm{kg}$ i.p.) and/or whole-body irradiation ( $3 \mathrm{~Gy}$ of gamma rays).

\section{Histone fractions}

In histones extracted from the testes of rats treated only with $\mathrm{CdCl} 2$, no changes were found in relative proportion of individual fractions (Fig. 2). After irradiation alone, the proportion of fraction $\mathrm{H} 1$ was increased from day 7 until the end of the experiment. The increase in $\mathrm{H} 1$ fraction was on account of $\mathrm{H} 2+\mathrm{H} 3$ fractions and on day 21 also on account of decrease in $\mathrm{H} 4$ fraction. The combination of the two treatments induced the same changes in relative proportion of histone fractions as irradiation alone with the exception of the 14th day, when an increase in $\mathrm{H} 1$ fraction and loss of $\mathrm{H} 4$ fraction was much more conspicuous than after irradiation alone.

The proportion of $\mathrm{H} 1 \mathrm{t}$ subfraction in the $\mathrm{H} 1$ fraction transiently increased on the days 1 and 14 after administration of cadmium alone (Fig. 3). After irradiation alone or in combination with cadmium, relative proportion of $\mathrm{H} 1 \mathrm{t}$ subfraction sharply increased on day 21 after the treatments in comparison to control. Temporary decreases in H1t subfraction, which occurred at the earlier intervals, were not statistically significant.

\section{H/DNA ratio}

In all groups of experimental rats, the ratio of histones to DNA was lowered in course of experiment with exception of day 14 after treatment (Table 1). At the first two intervals of examination, the decline in H/DNA ratio resulted from temporary increase in DNA concentration, whereas decline on day 21 was mainly due to the decrease in histone concentration.

Table 1

Ratio of histone to DNA concentrations (H/DNA) in testes of rats after administration of cadmium (3 mg/kg i.p.) and/or gamma irradiation (3 Gy).

\begin{tabular}{|l|c|c|c|c|}
\hline \multirow{2}{*}{ Group } & \multicolumn{4}{|c|}{ Days after treatment } \\
\cline { 2 - 5 } & 1 & 7 & 14 & 21 \\
\hline $\begin{array}{l}\text { Control } \\
\text { (C) }\end{array}$ & 2.34 & 2.34 & 2.21 & 2.20 \\
\hline $\begin{array}{l}\text { Cadmium } \\
(\text { Cd) }\end{array}$ & 1.32 & 1.23 & 2.34 & 1.83 \\
\hline $\begin{array}{l}\text { Irradiation } \\
\text { (Ir) }\end{array}$ & 1.91 & 1.32 & 2.48 & 1.65 \\
\hline $\begin{array}{l}\text { Cadmium + } \\
\text { irradiation Cd+Ir }\end{array}$ & 1.60 & 1.12 & 2.87 & 1.56 \\
\hline
\end{tabular}

\section{Discussion}

Administration of cadmium alone $(3 \mathrm{mg} \mathrm{CdCl} / 2 / \mathrm{kg}$ ) did not induce changes of histones in rat testes with the exception of transient increase in $\mathrm{H} 1 \mathrm{t}$ subtype in $\mathrm{H} 1$ histone fraction; an 
initial drop in H/DNA ratio in this group was due to increase in DNA concentration. In the other groups of experimental rats, the changes of histones were much more profound and majority of them appeared at later periods after treatments. After irradiation with gamma rays ( $3 \mathrm{~Gy}$ ) alone or in combination with cadmium, the content of histones in testes of rats gradually decreased until the end of investigation. The decrease in histone content was caused mainly by fall in $\mathrm{H} 4$ and $\mathrm{H} 2+\mathrm{H} 3$ fractions, therefore the relative proportion of $\mathrm{H} 1$ fraction increased. The decrease in concentration of histones on day 21 after irradiation alone or in combination with cadmium was accompanied by abrupt increase in H1t histone subtype. It seems, therefore, that $\mathrm{H} 4$ fraction is the most labile fraction of histones in rat testes; the most stable fraction seems to be $\mathrm{H} 1$ fraction, especially its subfraction $\mathrm{H} 1 \mathrm{t}$.

Decrease in histone content in the testes of treated rats is in agreement with findings of Dat ta et al. (1993) concerning the effects of ionizing radiation on various proliferating and non-proliferating tissues. Decrease in histone content without adequate decrease in DNA content can be explained by partial acetylation of some histone fractions occurring mainly in cells activated to proliferation and transcription (Kožurk ová et al. 1995; Ren and Tong 1997), because acetylation leads to weakening of electrostatic bonds between DNA and histones. In our experiment, especially at later intervals, the decrease in histone content in testes was related to fall in relative proportion of $\mathrm{H} 4$ fraction, which is acetylated in the highest degree. Preferential decrease in $\mathrm{H} 4$ fraction was found after irradiation also in other rat tissues, such as intact and regenerating liver and cerebellum (Kožurková et al. 1991; Klimová and Mišúrová 2003). On the other side, the alterations in total histone content and fall in relative proportion of $\mathrm{H} 4$ histone fraction were accompanied by increase in proportion of $\mathrm{H} 1$ fraction. Linker histone $\mathrm{H} 1$ undergoes acetylation in the lowest degree (Kožurková et al. 1995) and after irradiation it becomes transiently dephosphorylated (Guo et al. 2000) therefore the loss of H1 histone fraction due to weakening of its binding to DNA is improbable. The increase in relative proportion of $\mathrm{H} 1$ fraction might be related also to changes in extrachromatin pool of histones, which almost completely consists of the H1 fraction (Zlatanova et al. 1990).

H1t represents a testis-specific subtype of H1 histone occurring only in male germinal cells at the terminal stage of differentiation (Bucci et al. 1981; Ullrich et al. 1999). Synthesis of this subtype of histones was found in zygotenic or early pachytenic spermatocytes. The increase in relative proportion of H1t subtype, which was observed mainly in the testes of irradiated rats $(\mathrm{Ir}, \mathrm{Cd}+\mathrm{Ir})$ on the $21^{\text {st }}$ day after irradiation, can be, therefore, related to reappearance of spermatocytes at this time of regeneration of seminiferous epitelium.

In general, alterations induced by administration of cadmium $(3 \mathrm{mg} \mathrm{CdCl} / \mathrm{kg})$ alone were milder than those induced by gamma irradiation ( $3 \mathrm{~Gy}$ ) alone; however, the character of alterations was similar. In majority of cases, after combined treatment (cadmium being administered $30 \mathrm{~min}$ before irradiation), the alterations of histones were more profound than after single treatment. These findings suggest that partial summation of the two factor effects occurs after combined treatment.

\section{Účinky kadmia a ionizujúceho šiarenia na históny semenníkov potkanov}

Sledovali sme zmeny jednej zo zložiek chromatínu, histónov, v semenníkoch potkanov

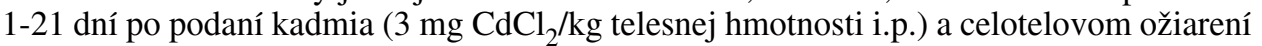
(3 Gy gama lúčov). Zistili sme, že podanie samotného kadmia nespôsobilo zmeny histónov; pomer H/DNA bol však znížený v dôsledku prechodného zvýšenia koncentrácie DNA. Samotné ožiarenie spôsobilo počiatočné zvýšenie koncentrácie a celkového obsahu histónov, ktoré bolo nasledované postupným poklesom obsahu histónov a zmenami relatívneho zastúpenia jednotlivých frakcií histónov do konca pokusu. Na 21. deň po 
samotnom ožiarení sme zistili prudký vzrast v zastúpení subfrakcie histónu H1, H1t. Po kombinácii zásahov (kadmium podané 30 min pred ožiarením) boli zmeny histónov podobné, ako po samotnom ožiarení, ale boli výraznejšie. Tento nález naznačuje čiastočnú sumáciu účinkov oboch zásahov na históny semenníkov.

\section{Acknowledgement}

The study was supported by grant project from the Ministry of Education and Science of the Slovak Republic No. $1 / 9205 / 02$.

\section{References}

BEATO, M, EISFELD, K 1997: Transcription factor access to chromatin. Nucl Acid Res 25: 3559-3563 BENCH, G, CORZETT, MH, MARTINELLI, R, BALHORN, R 1999: Cadmium concentrations in the testes, sperm and spermatids of mice subjected to long-term cadmium chloride exposure. Cytometry 35: 30-36

BERGER, SL 2002: Histone modifications in transcriptional regulation [Review]. Curr Opin Genet Develop 12: $142-148$ BUCCI, LR, BROCK, WA, MEISTRICH, ML 1981: Localisation of changes in H1 subtype composition and synthesis to specific cell types of the rat testes. J Cell Biol 91: 55-56

DATTA, R, WEICHSELBAUM, R, KUFE, DW 1993: Ionizing radiation down-regulates histone H1 gene expression by transcriptional and posttranscriptional mechanism. Radiat Res 133: 176-181

DE ROOIJ, DG, GROOTEGOED, JA 1998: Spermatogonial stem cells. Curr Opin Cell Biol 10: 694-701

FASANYAODEWUMI, C, LATINWO, LM, IKEDIOBI, CO, GILIARD, L, SPONHOLTZ, G, NWOGA, J, STINO, F, HAMILTON, N, ERDOS, GV 1998: The genotoxicity and cytotoxicity of dermally-administered cadmium: effects of dermal cadmium administration. Int J Mol Med 1: 1001-1006

GOBÉ, GC, HARMON, B, LEIGHTON, J, ALLAN, DJ 1999: Radiation-induced apoptosis and gene expression in neonatal kidney and testis with and without protein synthesis inhibition. Int J Radiat Biol 75: 973-983

GRÜNICKE, HH, YAMADA, Y, NATSUMEDA, Y, HELLIGER, W, PUSCHENDORF, G, WEBER, G 1989: Histone acetyltransferase activity in rat hepatomas. J Cancer Clin Oncol 115: 435-438

GUO, CY, MIZZEN, C, WANG, Y, LARNER, JM 2000: Histone H1 and H3 dephosphorylation are differentially regulated by radiation-induced signal transduction pathways. Cancer Res 60: 5667-5672

HARPER, J 1984: Basic programme of a robust multiple comparison test for statistical analysis of all differences among group means. Comput Biol Med 14: 437-445

KEETON, WT, GOULD, JL 1986: Biological Science. Norton WW and Comp, New York, 1175 p.

KELLEY, C 1999: Cadmium therapeutic agents. [Review]. Curr Pharm Des 5: 229-240

KLIMOVÁ, Š, MIŠÚROVÁ, E 2001: Effect of cadmium and ionizing radiation on DNA and RNA in the rat brain. Bull Veterinary Institute in Pulawy, Poland, 46: 127-137

KLIMOVÁ, Š, MIŚÚROVÁ, E 2003: Effect of cadmium and ionizing radiation on histones in rat brain. Trace Elem Electrolytes 20: 34-41

KOIZUMI, T, SHURAKURA, H, KUMAGAI, H, TATSUMOTO H, SUZUKI, KT 1996: Mechanism of cadmium-induced cytotoxicity in rat hepatocytes: cadmium-induced active oxygen-related permeability changes of the plasma membrane. Toxicology 114: 125-134

KORÉNEKOVÁ, B, SKALICKÁ, M, NAĎ, P 2002: Cadmium exposure of cattle after long-term emission from polluted area. Trace Elem Electrolytes 19: $97-99$

KOUZARIDES, T 2002: Histone methylation in transcriptional control [Review]. Curr Opin Genet Develop 12: 198-209

KOŽURKOVÁ, M, MIŠÚROVÁ, E, KROPÁČOVÁ, K, REXA, 1991: The effect of single, continuous and combined gamma radiation on histones in intact and regenerating liver in rats. In: BODA, K (Ed).: Current Trends in Cosmic Biology and Medicine II. Ivanka pri Dunaji, pp.151-158

KOŽURKOVÁ, M, MIŠÚROVÁ, E, KROPÁČOVÁ, K 1995: Effect of aging and gamma radiation on acetylation of rat liver histones. Mech Age Dev 78: 1-14

LOWRY, OH, ROSENBROUGH, NJ, FARR, AR, RANDALL, RJ 1951: Protein measurement with the Folin phenol reagent. J Biol Chem 193: 265-275

OKI, M, KAMAKAKA, RT 2002: Blockers and barriers to transcription: competing activities? [Review]. Curr Opin Cell Biol 14: 299-304

OTEIZA, PI, ADONAYLO, VN, KEEN, CL 1999: Cadmium-induced testes oxidative damage in rats can be influenced by dietary zinc intake. Toxicology 137: 13-22

PANYIM, S, CHALKLEY, R 1969: High-resolution acrylamide gel electrophoresis of histones. Arch Biochem Biophys 2: 337-346

REN, QH, TONG, TJ 1997: Histone acetylation and its roles in transcriptional regulation. Prog Biochem Biophys 24: $309-312$

SMERDON, MJ, CONCONI, A 1999: DNA modulation of damage and DNA repair in chromatin. Prog Nucleic Acid Res: Mol Biol 62: 227-255 
SMITH, JB, PIJUAN, B, ZHUANG, V, CHEN, YC 1994: Transmembrane signals and protooncogene induction evoked by carcinogenic metals and prevented by zinc. Environ Health Perspect 105: 81-89

ULLRICH, O, SITTE, N, SOMMERBURG, O, SANDIG, V, DAVIES, KJ, GRUNE, T 1999: Influence of DNA binding on the degradation of oxidized histones by the $20 \mathrm{~S}$ proteasome. Arch Biochem Biophys 362: 211-216 VAN BUUL, PPW, GOUDZWAARD, JH 1990: The relation between induced reciprocal translocations and cell killing of mouse spermatogonial stem cells after combined treatments with hydroxyurea and X-rays. Mutat Res 243: $259-266$

WAALKES, MP 2000: Cadmium carcinogenesis in review. J Inorg Biochem 79: 241-244

XU, C, JOHNSON, JE, SINGH, PK, JONES, MM, YAN, H, CARTER, CE 1996: In vivo studies of cadmiuminduced apoptosis in testicular tissue of the rat and its modulation by a chelating agent. Toxicology 107: 1-8

YAN, H, CARTER, CE, XU, C, SINGH, PK, JONES, MM, JOHNSON, JE, DIETRICH, MS 1997: Cadmiuminduced apoptosis in the urogenital organs of the male rat and its suppression by chelaton. $\mathrm{J}$ Toxicol Environ Health 52: 149-168

ZLATANOVA, J 1990: Histone H1 and the regulation of transcription of eukaryotic genes. Trends Biochem 15: 273-276

ZHOU, T, ZHOU, G, SONG, W, EGUCHI, N, LU, W, LUNDIN, E, JIN, T, NORDBERG, G 1999: Cadmiuminduced apoptosis and changes in expression of p53, c-jun and MT-I genes in testes and ventral prostate of rats. Toxicology 142: 1-13 